\title{
PERBEDAAN HEMOGLOBIN REMAJA PUTRI YANG MENDAPATKAN DENGAN YANG TIDAK MENDAPATKAN TABLET TAMBAH DARAH PEMERINTAH
}

\section{DIFFERENCES OF HEMOGLOBIN ADOLESCENT PRINCESSES GETTING WITH NOT GETTING ADDITIONAL BLOOD TABLETS GOVERNMENT}

\author{
Yeti Septiasari \\ Fakultas Kesehatan Universitas Muhammadiyah Pringsewu \\ Email: yetiseptiasarinew@yahoo.co.id
}

\begin{abstract}
Differences Of Hemoglobin Adolescent Princesses Getting With Not Getting Additional Blood Tablets Government. Pringsewu Regency currently has a PPAGB program to tackle anemia in adolescents. One of the Puskesmas that runs it is Ambarawa Puskesmas. The purpose of this study was to determine differences in hemoglobin levels in adolescent girls who get government blood-added tablets in the Ambarawa Public Health Center High School. This study researchers used analytic observational methods with a cross sectional approach. This study has two independent variables, namely differences in hemoglobin levels in girls who are in Ambarawa High School who received Government TTD and who did not get Government TTD in Ambarawa High School. So the total sample is 50 people. The sampling method used was random sampling. instrument for measuring hemoglobin levels using rapid tests. Data analysis using independent paired T-test with a 95\% confidence level. The results showed that teenagers who routinely get the Fe tablet as much as $52 \%$. The average hemoglobin level in adolescents receiving Fe supplementation was 11.5 (1.79) $\mathrm{gr} / \mathrm{dl}$. the average hemoglobin level in adolescents receiving Fe supplementation was 11.5 (1.79) gr / dl. Obtained Mean Difference value of -0.22298 , the statistical test results obtained $p$ value 0.657 . This means that Ho was accepted and $\mathrm{Ha}$ was rejected so that it can be concluded that there was no difference in hemoglobin levels of young women who received the Fe supplementation intervention program and those who did not receive Fe supplementation in the high school working area of the Ambarawa Puskesmas.

Keywords: iron supplementation, teenage girl
\end{abstract}

\begin{abstract}
Abstrak: Perbedaan Hemoglobin Remaja Putri Yang Mendapatkan Dengan Yang Tidak Mendapatkan Tablet Tambah Darah Pemerintah Kabupaten Pringsewu saat ini telah menjalankan program PPAGB untuk menanggulangi anemia pada remaja. Salah satu Puskesmas yang menjalankannya adalah Puskesmas Ambarawa. Tujuan penelitian ini adalah mengetahui Perbedaan Kadar Hemoglobin Pada Remaja Putri Yang Mendapatkan Tablet Tambah Darah Pemerintah Di SMA Wilayah Kerja Puskesmas Ambarawa. penelitian ini peneliti menggunakan metode observasional analitik dengan pendekatan cross sectional. Penelitian ini memiliki dua variabel independen (bebas) yaitu perbedaan kadar hemoglobin remaja putri yang di SMA Ambarawa yang mendapat TTD Pemerintah dan yang tidak mendapatkan TTD Pemerintah di SMA Ambarawa. Jadi total sampel adalah 50 orang. Metode sampling yang digunakan adalah random sampling. instrument pengukuran kadar hemoglobin dengan menggunakan rapid test. Analisis data menggunakan uji T-test independent tidak berpasangan dengan tingkat kepercayaan $95 \%$. Hasil penelitian didapatkan remaja yang rutin mendapatkan tablet fe sebanyak $52 \%$. Ratarata kadar hemoglobin pada remaja yang mendapatkan suplementasi fe adalah $11,5(1,79) \mathrm{gr} / \mathrm{dl}$. rata-rata kadar hemoglobin pada remaja yang mendapatkan suplementasi fe adalah $11,5(1,79)$ $\mathrm{gr} / \mathrm{dl}$. Didapatkan nilai Mean Difference sebesar -0,2298, Hasil uji statistik didapatkan $\mathrm{p}$ value 0,657. Hal ini berarti Ho diterima dan Ha ditolak sehingga dapat disimpulkan tidak ada perbedaan Kadar Hemoglobin remaja putri yang mendapatkan program intervensi suplementasi Fe dengan yang tidak mendapatkan suplementasi fe di SMA wilayah kerja Puskesmas Ambarawa Kata kunci: suplementasi TTD, remaja putri
\end{abstract}




\section{PENDAHULUAN}

Populasi remaja di Indonesia mencapai $20 \%$ dari total populasi penduduk Indonesia, yaitu sekitar 30 juta jiwa (Rachmadianto, 2014). Asupan nutrisi yang adekuat diperlukan terutama untuk zat besi pada usia 14-18, terutama untuk remaja putri (15 mg untuk wanita dibandingkan dengan $11 \mathrm{mg}$ untuk lakilaki $11 \mathrm{mg}$ ), hal ini dikarenakan untuk metabolisme biologis seperti menarche dan peningkatan kebutuhan zat besi dari menstruasi bulanan (Cristian, 2018).z

World Health Organization (WHO) menyebutkan bahwa banyak masalah gizi pada remaja masih terabaikan, disebabkan karena masih banyak faktor-faktor yang belum diketahui, padahal remaja merupakan sumber daya manusia Indonesia yang harus dilindungi karena potensinya yang sangat besar dalam upaya pembangunan kualitas bangsa (Rachmadianto, 2014). Prevalensi anemia remaja di Indonesia berdasarkan kelompok umur, penderita anemia berumur 5-14 tahun sebesar 26,4\% dan sebesar $18,4 \%$ pada kelompok umur 15-24 tahun. (Riskesdas, 2013). Prevalensi defisiensi zat besi dan anemia defisiensi besi lebih tinggi di kalangan wanita remaja dibandingkan laki-laki (Christian, 2018).

Remaja putri (10-19 tahun) merupakan salah satu kelompok yang rawan mengalami anemia. Remaja putri merupakan generasi masa depan bangsa yang nantinya akan menentukan generasi berikutnya (Permatasari, 2018). Periode remaja membutuhkan asupan zat besi yang lebih tinggi karena pertumbuhan tubuh yang cepat. Jadi, risiko anemia meningkat selama masa remaja Anemia adalah kondisi di mana jumlah sel darah merah atau kapasitas pembawa oksigen tidak cukup untuk memenuhi kebutuhan fisiologis. Penyebab paling umum adalah defisiensi zat besi; penyebab lainnya adalah kekurangan vitamin B12, peradangan kronis, parasit infeksi, dan gangguan hemoglobin genetik (Yasutake dkk, 2013).

Hal serupa juga dijelaskan oleh penelitian Srivastava (2016) yang menjelaskan proporsi lebih tinggi pada kasus anemia berusia antara 13-15 tahun. Hubungan signifikan anemia ditemukan di antara mereka yang memiliki status sosial ekonomi rendah, peningkatan ukuran keluarga dan kurang pendidikan orang tua. Penting untuk memperkuat pendidikan kesehatan pada konsumsi makanan kaya zat besi dan implementasi program intervensi yang tepat yang akan meningkatkan kadar hemoglobin di antara kelompok usia remaja, melalui perawatan program profilaksis di sekolah dan modifikasi pola makan.

Anemia dapat menurunkan performa belajar remaja. Penelitian di Italia menjelaskan ada hubungan antara nutrisi siswa dengan performa di sekolah. Beberapa penelitian menjelaskan dampak negatif yang ditimbulkan dari kekurangan nutrisi seperti kesulitan dalam belajar. Beberapa peneliti menjelaskan dampak dari anemia besi dapat menyebabkan gangguan belajar. Namun demikian intervensi suplementasi besi dapat meningkatkan kemampuan kognitif siswa (Aquilani dkk, 2011). Penelitian ini menunjukkan bahwa performa remaja putri di sekolah berhubungan positif dengan diet besi. Sehingga suplementasi fe dan asupan makanan dapat memengaruhi fungsi otak dan kognitif (Aquilani dkk, 2011).

Pemerintah menyelenggarakan kegiatan kesehatan remaja untuk meningkatkan kualitas remaja. Cakupan Puskesmas yang menyelenggarakan kesehatan remaja di Indonsesia adalah 42,67 \%. Provinsi lampung terdapat 224 Puskesmas (76,71\%) dari 292 Puskesmas yang menyelenggarakan kesehatan remaja.Program pemerintah Indonesia yang fokus terhadap penanggulangan anemia remaja putri yakni Program Pencegahan dan Penanggulangan Anemia Gizi Besi (PPAGB) dengan sasaran anak Sekolah Menengah Pertama (SMP) dan Sekolah Menengah Atas (SMA) melalui pemberian suplementasi kapsul zat besi (Permatasari, 2018).

Penelitian oleh Rachmadianto (2014) menjelaskan bahwa pemberian suplementasi besi secara efektif dapat meningkatkan kadar hemoglobin pada siswi. Dari hasil penelitian ini menunjukan ada perubahan kadar hemoglobin siswi sebelum dan sesudah pemberian Tablet Tambah Darah. Suplementasi Tambah darah akan meningkatkan oksigenasi dalam sel menjadi lebih baik, metabolisme ningkat dan fungsi sel akan optimal sehingga daya serap makanan menjadi lebih baik.

Sebuah studi intervensi dilakukan di antara 104 gadis remaja yang belum menikah di India dengan tujuan untuk mempelajari pengaruh perubahan dalam perilaku diet dan suplementasi besi untuk mengurangi anemia defisiensi besi. Remaja putri diberikan zat besifolat dan kalsium selama 3 bulan. Hasil penelitian menunjukkan ada peningkatan hemoglobin pada kelompok perempuan yang menerima suplemen sedangkan hemoglobin sedikit menurun pada anak perempuan di kelompok kontrol. Kesimpulannya, 
mempertimbangkan kelayakan biologis dan efektivitas intervensi, suplementasi besi harus dimulai dan diet perilaku harus ditingkatkan pada remaja perempuan untuk pencegahan anemia (Bhanushali, 2011).

Upaya pemerintah dalam menanggulangi masalah anemia gizi tidak selalu berjalan dengan baik dan efektif. Penelitian Kheirouri dalam Permatasari (2018) menyebutkan bahwa selain ketersediaan tablet besi dan efek samping yang ditumbulkan oleh tablet, terdapat faktor lainnya yang dapat memengaruhi keefektifan program suplementasi besi yaitu dipengaruhi kualitas TTD, cara sosialisasi kepada remaja putri, peran orangtua, kerjasama stakeholder, serta pelatihan edukator.

Pelayanan Kesehatan Remaja di Kabupaten Pringsewu cakupan pemeriksaan remaja usia tahun 2016 telah mencakup 72\%, lebih rendah bila dibandingkan tahun sebelumnya yaitu 98,7\%. Kabupaten Pringsewu saat ini telah menjalankan program PPAGB untuk menanggulangi anemia pada remaja. Salah satu Puskesmas yang menjalankannya adalah Puskesmas Ambarawa. Sampai saat ini belum ada penelitian yang mengevaluasi keberhasilan dari program tersebut. Penelitian ini bertujuan untuk mengetahui Perbedaan Kadar Hemoglobin Pada Remaja Putri Yang Mendapatkan Tablet Tambah Darah Pemerintah Di SMA Wilayah Kerja Puskesmas Ambarawa.

\section{METODE}

Pada penelitian ini peneliti menggunakan metode observasional analitik dengan pendekatan crossectional. Peneliti tidak melihat hubungan antara variabel berdasarkan perjalanan waktu namun dalam penelitian ini akan melihat perbedaan kadar hemoglobin remaja putri yang di SMA Ambarawa yang mendapat TTD Pemerintah dan yang tidak mendapatkan TTD Pemerintah di SMA Ambarawa. Populasi pada penelitian ini adalah seluruh remaja putri di SMA Ambarawa yang berjumlah 450 orang. Total sampel adalah 50 orang. Pada penelitian ini menggunakan kelas XI (kelas 2) karena secara adaptasi di sekolah lebih baik dan jadwal belum padat seperti kelas XII. Penelitian ini telah dilaksanakan selama Oktober-November 2019 di wilayah SMA wilayah Puskesmas Ambarawa. Metode sampling yang digunakan adalah random sampling yaitu teknik penentuan sampel berdasarkan system acak, yaitu memilih 1 SMA yang menggunakan TTD program pemerintah dan 1 SMA yang belum menggunakan TTD program pemerintah. Pada instrument ini menggunakan instrument pengukuran kadar hemoglobin dengan menggunakan rapid test. Peneliti melakukan analisa bivariat terhadap 2 (dua) variabel yaitu menganalisis perbedaan kadar hemoglobin remaja putri, dengan menggunakan uji T-test independent tidak berpasangan dengan tingkat kepercayaan 95\% atau dapat pula dengan perbandingan nilai $\mathrm{p}$ value dengan nilai $\alpha=0,05$

HASIL

Tabel 1 Gambaran Remaja Putri Yang Mendapatkan Dan Tidak Mendapatkan Suplementasi Fe Di SMA Wilayah Kerja Puskesmas Ambarawa

\begin{tabular}{lll}
\hline $\begin{array}{l}\text { Suplementasi } \\
\text { Fe }\end{array}$ & Frekuensi & Persentase \\
\hline Tidak & 24 & 48 \\
Diberikan Fe & & \\
Diberikan Fe & 26 & 52 \\
\hline
\end{tabular}

Pada tabel 1 didapatkan remaja yang rutin mendapatkan tablet fe sebanyak $52 \%$, sedangkan yang tidak mendapatkan tablet fe sebanyak $48 \%$.

Tabel 2 Kadar Hemoglobin Pada Remaja Yang Mendapatkan Dan Tidak Mendapatkan Suplementasi Fe Di SMA Wilayah Kerja Puskesmas Ambarawa

\begin{tabular}{llllll}
\hline $\begin{array}{l}\text { Kadar } \\
\text { Hb }\end{array}$ & $\begin{array}{l}\text { Mea } \\
\text { n }\end{array}$ & SD & $\begin{array}{l}\text { Media } \\
\mathbf{n}\end{array}$ & $\begin{array}{l}\text { Rentan } \\
\mathbf{g}\end{array}$ \\
\hline $\begin{array}{l}\text { Rutin } \\
\text { Diberika }\end{array}$ & 11,5 & 1,7 & 11,7 & $7,6-14,5$ \\
n Fe & & 9 & & & \\
\hline $\begin{array}{l}\text { Tidak } \\
\text { Diberika } \\
\text { n Fe }\end{array}$ & 11,7 & 1,8 & 12,1 & 7,8 & - \\
\hline
\end{tabular}

Pada tabel 2 diinformasikan bahwa rata-rata kadar hemoglobin pada remaja yang mendapatkan suplementasi fe adalah $11,5(1,79)$ $\mathrm{gr} / \mathrm{dl}$, dengan nilai rentang 7,6-14,5. Sedangkan rata-rata kadar hemoglobin pada remaja yang mendapatkan suplementasi fe adalah 11,5(1,79) gr/dl, dengan nilai rentang 7,8-15,3. 
Tabel 3 Perbandingan Kadar Hemoglobin Remaja Putri Yang Mendapatkan Program Intervensi Suplementasi Fe Dengan Yang Tidak Mendapatkan Suplementasi Fe Di SMA Wilayah Kerja Puskesmas Ambarawa

\begin{tabular}{lllll}
\hline $\begin{array}{l}\text { Suplementa } \\
\text { si Fe }\end{array}$ & MD & SED & $\begin{array}{l}\text { P } \\
\text { valu } \\
\text { e }\end{array}$ & t \\
\hline & - & 0,514 & 0,65 & - \\
& 0,229 & 5 & 7 & 0,44 \\
8 & & & 7 \\
\hline
\end{tabular}

Pada tabel 3 didapatkan nilai Mean Difference sebesar -0,2298, Hasil uji statistik didapatkan $p$ value 0,657 . Hal ini berarti Ho diterima dan $\mathrm{Ha}$ ditolak sehingga dapat disimpulkan tidak ada perbedaan Kadar Hemoglobin remaja putri yang mendapatkan program intervensi suplementasi $\mathrm{Fe}$ dengan yang tidak mendapatkan suplementasi fe di SMA wilayah kerja Puskesmas Ambarawa.

\section{PEMBAHASAN}

Pada tabel 4.1 didapatkan remaja yang rutin mendapatkan tablet fe sebanyak 52\%, sedangkan yang tidak mendapatkan tablet fe sebanyak $48 \%$.

Tablet tambah darah adalah suplemen gizi yang mengandung senyawa zat besi yang setara dengan $60 \mathrm{mg}$ besi elemental dan 400 mcg asam folat. Kesetaraan besi elemental dan tingkat bioavailablitasnya berbeda berdasarkan senyawa besi yang digunakan. Oleh karenanya, TTD program dan TTD mandiri harus mengacu pada ketentuan tersebut (Kemenkes, 2015).

Pemberian TTD secara rutin selama jangka waktu tertentu bertujuan untuk meningkatkan kadar hemoglobin secara cepat, dan perlu dilanjutkan untuk meningkatkan simpanan zat besi didalam tubuh. Apabila pola makan sudah memenuhi gizi seimbang, maka suplementasi TTD tidak diperlukan lagi. Oleh karena itu perlu selalu dilakukan pendidikan mengenai pola makan bergizi seimbang, selain perlu memberikan pendidikan mengenai pentingnya konsumsi TTD terutama untuk ibu hamil. Konsumsi TTD masih diperlukan oleh masyarakat Indonesia, terutama karena pada umumnya pola makan masyarakat kurang kaya zat besi (Kemenkes RI, 2015)

Pemerintah menyelenggarakan kegiatan kesehatan remaja untuk meningkatkan kualitas remaja. Cakupan Puskesmas yang menyelenggarakan kesehatan remaja di Indonsesia adalah 42,67 \%. Provinsi lampung terdapat 224 Puskesmas (76,71\%) dari 292 Puskesmas yang menyelenggarakan kesehatan remaja.Program pemerintah Indonesia yang fokus terhadap penanggulangan anemia remaja putri yakni Program Pencegahan dan Penanggulangan Anemia Gizi Besi (PPAGB) dengan sasaran anak Sekolah Menengah Pertama (SMP) dan Sekolah Menengah Atas (SMA) melalui pemberian suplementasi kapsul zat besi (Permatasari, 2018)

Pada hasil penelitian ini jumlah cakupan lebih rendah dari cakupan yang ada di Kabupaten pringsewu. Pelayanan Kesehatan Remaja di Kabupaten Pringsewu cakupan pemeriksaan remaja usia tahun 2016 telah mencakup $72 \%$, lebih rendah bila dibandingkan tahun sebelumnya yaitu 98,7\%. Kabupaten Pringsewu saat ini telah menjalankan program PPAGB untuk menanggulangi anemia pada remaja.

Pada tabel 4.2 diinformasikan bahwa rata-rata kadar hemoglobin pada remaja yang mendapatkan suplementasi fe adalah 11,5(1,79) $\mathrm{gr} / \mathrm{dl}$, dengan nilai rentang 7,6-14,5. Sedangkan rata-rata kadar hemoglobin pada remaja yang mendapatkan suplementasi fe adalah 11,5(1,79) gr/dl, dengan nilai rentang 7,8-15,3. Berdasarkan hal tersebut rata-rata kedua kelompok masih berada pada kondisi anemia.

WHO menjelaskan bahwa anemia pada remaja merupakan kondisi defisiensi tubuh dengan indikasi kadar haemoglobin $<12 \mathrm{gr} / \mathrm{dl}$ atau lebih rendah dari batas normalnya. Anemia merupakan indicator dari kesehatan dan nutrisi yang kurang (WHO, 2011). Batasan anemia pada remaja putri adalah $<12$ gr/dl. Pada hasil penelitian ini rata-rata remaja putri mengalami anemia pada kedua kelompok.

Asupan nutrisi yang adekuat diperlukan terutama untuk zat besi pada usia 14-18, terutama untuk remaja putri $(15 \mathrm{mg}$ untuk wanita dibandingkan dengan $11 \mathrm{mg}$ untuk lakilaki $11 \mathrm{mg}$ ), hal ini dikarenakan untuk metabolisme biologis seperti menarche dan peningkatan kebutuhan zat besi dari menstruasi bulanan (Cristian, 2018).

Anemia menyebabkan gangguan kesehatan yang dapat dialami semua kelompok umur. Defisiensi besi walaupun belum disertai anemia defisiensi besi dan anemia ringan sudah cukup menimbulkan gejala, seperti lesu, lemah, letih, lelah, dan lalai (5 L). Hal ini diakibatkan oleh menurunnya kadar oksigen yang dibutuhkan jaringan tubuh, termasuk otot untuk aktivitas fisik dan otak untuk berpikir, karena oksigen dibawa oleh hemoglobin. Penderita kekurangan zat besi juga akan turun daya tahan 
tubuhnya, akibatnya mudah terkena penyakit infeksi. Anemia pada masa remaja berisiko untuk terjadinya defisiensi besi pada saat hamil, oleh karena kehamilan meningkatkan kebutuhan terhadap zat besi secara sangat signifikan (Kemenkes RI, 2015)

Pada tabel 3 didapatkan nilai Mean Difference sebesar -0,2298, Hasil uji statistik didapatkan $p$ value 0,657 . Hal ini berarti Ho diterima dan $\mathrm{Ha}$ ditolak sehingga dapat disimpulkan tidak ada perbedaan Kadar Hemoglobin remaja putri yang mendapatkan program intervensi suplementasi $\mathrm{Fe}$ dengan yang tidak mendapatkan suplementasi fe di SMA wilayah kerja Puskesmas Ambarawa.

Anemia dapat menurunkan performa belajar remaja. Penelitian di Italia menjelaskan ada hubungan antara nutrisi siswa dengan performa di sekolah. Beberapa penelitian menjelaskan dampak negatif yang ditimbulkan dari kekurangan nutrisi seperti kesulitan dalam belajar. Beberapa peneliti menjelaskan dampak dari anemia besi dapat menyebabkan gangguan belajar. Namun demikian intervensi suplementasi besi dapat meningkatkan kemampuan kognitif siswa (Aquilani dkk, 2011).

Hasil penelitian ini berbeda dengan penelitian oleh Rachmadianto (2014) menjelaskan bahwa pemberian suplementasi besi secara efektif dapat meningkatkan kadar hemoglobin pada siswi. Dari hasil penelitian ini menunjukan ada perubahan kadar hemoglobin siswi sebelum dan sesudah pemberian Tablet Tambah Darah. Suplementasi Tambah darah akan meningkatkan oksigenasi dalam sel menjadi lebih baik, metabolisme ningkat dan fungsi sel akan optimal sehingga daya serap makanan menjadi lebih baik.

Upaya pemerintah dalam menanggulangi masalah anemia gizi tidak selalu berjalan dengan baik dan efektif. Penelitian Kheirouri dalam Permatasari (2018) menyebutkan bahwa selain ketersediaan tablet besi dan efek samping yang ditumbulkan oleh tablet, terdapat faktor lainnya yang dapat memengaruhi keefektifan program suplementasi besi yaitu dipengaruhi kualitas TTD, cara sosialisasi kepada remaja putri, peran orangtua, kerjasama stakeholder, serta pelatihan edukator.

Berdasarkan hasil utama laporan Riset Kesehatan Dasar (Riskesdas) tahun 2018 menjelaskan bahwa sebanyak $76,2 \%$ remaja putri mendapat tablet tambah darah. Remaja yang mengkonsumsi $<52$ butir $98,6 \%$, sedangkan yang mengkonsumsi $>52$ butir sebanyak $1,4 \%$. Hal ini menjelaskan bahwa remaja yang mendapat tablet tambah darah belum tentu dikonsumsi oleh remaja tersebut karena kapatuhan masih rendah.

Selain faktor suplementasi TTD dan menstruasi penyebab anemia juga disebabkan Konsumsi makanan sumber zat besi yang kurang, terutama yang berasal dari hewani, Kebutuhan yang meningkat karena, menstruasi pada perempuan dan tumbuh kembang masa remaja, Menderita penyakit infeksi, yang dapat berakibat zat besi yang diserap tubuh berkurang (kecacingan), atau hemolisis sel darah merah (malaria).

Berdasarkan hasil analisis diatas dapat ditarik kesimpulan bahwa tidak ada perbedaan bermaknna antara remaja yang mendapat dan tidak mendapat tablet tambah darah di wilayah kerja Puskesmas Ambarawa

\section{SIMPULAN}

Tidak ada perbedaan Kadar Hemoglobin remaja putri yang mendapatkan program intervensi suplementasi $\mathrm{Fe}$ dengan yang tidak mendapatkan suplementasi fe di SMA wilayah kerja Puskesmas Ambarawa

\section{SARAN}

Disarankan bagi pengambil kebijakan untuk melakukan program pendidikan kesehatan pada remaja putri sebelum memberikan tablet tambah darah agar peningkatan kepatuhan TTD.

Disarankan untuk melakukan kerja sama dengan tenaga kesehatan untuk melakukan pendidikan kesehatan rutin tentang anemia pada remaja putri.

\section{DAFTAR PUSTAKA}

Aquilani R, Dkk. (2011). School Performance Is Associated With Dietary Iron And Zinc Intake In Adolescent Girls. New Century Health Publishers. Vo.09. No.03. Hal 7176

Kemenkes RI. (2015). Buku Pedoman Pemberian Tablet Tambah Darah.

Kemenkes RI. Jakarta

Permatasari T, Briawan D. Madanijah. Efektivitas Program Suplementasi Zat Besi 
pada Remaja Putri di Kota Bogor. Jurnal MKMI. Vol.14.No.01. Hal 1-8

Rachmadianto NT. (2014). Efektivitas Pemberian Tablet Tambah Darah Terhadap Kadar HB Siswi SLTPN 1 Donorojo Kecamatan Donorojo Kabupaten Pacitan. Universitas Muhammadiyah Surakarta. Fakultas Keguruan dan Ilmu Pendidikan. Naskah Publikasi. Skripsi.

Riskesdas. (2018). Riset Kesehatan Dasar. Jakarta. Kementrian Kesehatan RI

Srivastava A, Kumar R. Sharma M. Nutritional anaemia in adolescent girls: an epidemiological study. International Journal of Community Medicine and Public Health. Vol 3. No.3. Hal 080.812

WHO. (2011). Haemoglobin concentrations for the diagnosis of anaemia and assessment of severity. Geneva

WHO. (2011). Prevention Of Iron Deficiency anaemia in Adolescents. Geneva

WHO. (2011). Global Prevalence of Anaemia.

Geneva 